\section{Kanada'da Temsili Bürokrasi Uygulamaları}

\author{
Representative Bureaucracy Practices in Canada
}

Strategic Public Management Journal Volume 4, Issue 8, pp.81-94 December 2018 DOI: $10.25069 /$ spmj.474153 Received: 24.10.2018 Accepted: 27.12.2018 (C) The Author(s) 2018 For reprints and permissions: http://dergipark.gov.tr/spmj

\author{
Namık Kemal ÖZTÜRK ${ }^{1}$ \\ Özge HAMEŞ 2
}

$\ddot{O} z$

Günümüzde neredeyse bütün toplumlar etnik, dil, din, kültür, renk gibi unsurlar sebebiyle birbirinden farklı insanların yanı sıra özellikle kadın ve engelli gibi bazı hususlarda dezavantajlı gruplardan oluşmaktadır. Bu insanların yaşadıkları toplumda gündelik yaşantılarına devam edebilmeleri, temel ihtiyaçlarını karşılayabilmeleri çalışma hayatına diğer insanlarla eşit koşullarda ve firsatlarla katılabilmelerine bağlıdır. Toplumsal yapıda meydana gelen çeşitliliğe paralel olarak artan iş gücü çeşitliliğini yönetmek için ülkelerin kamu sektörü açısından da çalışma hayatına ilişkin birtakım özel düzenlemeler yapması gerektiği ortaya çıkmıştır. Temsili bürokrasi, bürokraside azınlık ve dezavantajl grupların temsilinde eşit firsatlara sahip olunması, işe alınmalarında liyakat dışında her türlü ayrımcılığın yasaklanması anlamlarına gelmektedir. Bu sayede kamuya yapılacak hizmetler hususunda herkesin katılımının sağlanacağı, herkese eşit kamu hizmeti verilebileceği ve hizmetten yaralananlar arasında ayırım yapılmasının engellenebileceği vurgulanmıştır. Bu çalışmada toplumun genel yapısının bürokraside temsil edilmesi anlamına gelen temsili bürokrasi kavramı açıklanmaya çalışılmış ve bunun başarılı örneklerinden biri olan Kanada bürokratik sisteminde temsili bürokrasinin gelişimi ve uygulamaları ele alınmıştır.

Anahtar Kelimeler: Temsili Bürokrasi, Kanada, Toplumsal Gruplar, Engelli, Kadın

\title{
Abstract
}

Today, almost all societies are composed of different people due to factors such as ethnicity, language, religion, culture and color in addition to disadvantaged groups, in particular women and disabled people. The ability of these people to continue their daily lives in the society, to meet their basic needs depends on their ability to participate in working life with other people in equal conditions and opportunities. In order to manage the increasing diversity of workforce parallel to the diversity in the social structure, it has been revealed that countries should make some special arrangements regarding the working life in terms of the public sector. At this point, the concept of representing the general structure of the society emerged in bureaucracy. Representative bureaucracy has developed on issues such as having equal opportunities in representation of minorities and disadvantaged groups in the bureaucracy, prohibiting all forms of discrimination other than merit in recruitment. In this way, it was emphasized that everyone's participation in the services to be made to the public will be ensured, equal public service can be given to everyone and the separation between those who benefit from the service can be prevented. In this study, it is tried to explain the concept of representative

${ }^{1}$ Prof. Dr., Muğla Sttkı Koçman Üniversitesi, Kamu Yönetimi Bölümü, nkozturk@mu.edu.tr

2 Doktora Öğrencisi, Muğla Sttkı Koçman Üniversitesi, Kamu Yönetimi Bölümü, ozgehames@ gmail.com 
bureaucracy which represents the general structure of the society in bureaucracy and the development and applications of representative bureaucracy in the Canadian bureaucratic system which is one of the successful examples of this.

Key Words: Representative Bureaucracy, Canada, Social Groups, Disabled, Women.

\section{GİRIŞ}

Ülkelerin gittikçe çeşitlenen toplumsal yapılarının sonucunda işgücü de çeşitlenmiş ve bunların kontrol ve yönetimi, çalışma şart ve koşullarında eşitliğin sağlanması, işin gerekleri ve liyakat dışında her türlü ayrımcılığın yasaklanması gibi hususlar hükümetlerin çalışma hayatına yönelik dikkat etmesi gereken hususlardan en önemlilerinden biri haline gelmiştir. Hizmet edilen nüfusun çeşitliliği ile hizmet edecek işgücünün çeşitliliği bürokraside eşit ve orantılı temsil konusunu gündeme getirmiştir. Temsili bürokrasi, kamu görevi ifa edenler arasında toplumdaki azınlık veya dezavantajlı bütün unsurların eşit ve orantılı olarak yer alması üzerine kurgulanmıştır. Bu temsil sadece sosyo-demografik açıdan etnik, dil, din, renk, kültür gibi farklılığı olan insanların eşit temsili ile sınırlı olmamakta, aynı zamanda kadın, engelli gibi hususlarda dezavantajı olan grupların da temsilde adaletinin sağlanmasını içermektedir. Kamuda görev alacak azınlık veya dezavantajlı kişilerin bürokratik kademelerde yer almaları açısından diğerleriyle eşit firsatlara sahip olmaları sonucunda demokratik sistemin zarar görmeyeceği, herkesin katılımıyla karar ve hizmetlerin meşruiyetinin sağlanacağı, ülkede yaşayan tüm toplumsal gruplara eşit kamu hizmeti verilebileceği ve hizmetten yaralananlar arasında ayırım yapılmasının engellenebileceği söylenebilir (Öztürk, 2017:72). İngiltere ve ABD azınlık veya dezavantajlıların çalışma ve iş hayatlarını "İnsan Hakları" bağlamında hak ve özgürlükler açısından ele almış ve konuya ilişkin ilk düzenlemeleri yapmışlardır. Bu ülkeler sadece özel sektörde çalışma ve çalışma koşullarına ilişkin düzenlemeler yapmakla yetinmemişler, aynı zamanda kamu sektörü açısından da birtakım özel düzenlemelere gitmişlerdir. Kamu sektöründe çalışma koşulları herkese eşit firsat verecek şekilde düzenlenmiş, işe alma ve yükselme kriterlerinde her türlü ayrımcılık yasaklanmıştır. Toplumda var olan bütün farklılıkların bürokratik kademelerde eşit veya eşite yakın şekilde temsil edilmesi anlamına gelen temsili bürokrasi kavramı ilk olarak bu ülkelerde ortaya çıkmıştır. Bürokrasi merkez veya yerel yönetimler tarafından ortaya konan kamu politikalarının yürütülmesini kapsamakta ve çok geniş bir faaliyet alanındaki görevlileri ifade etmektedir. Durum böyle olunca da aslında kamu görevlisinin kimliği, dili, dini, engeli gibi hususlardan dolayı herhangi ayrımcılığa uğramaması, kamu görevlisinin işe alınırken görevin gerektirdiği liyakat ve yetenek dışında başka hususlardan dolayı herhangi ayrıma tabi olmaması, görev ve sorumluluklarını yerine getirip getirmediği gibi noktalara bakılması gerekmekte, bu sayede de kamuoyuna karşı daha duyarlı ve sorumlu bir şekilde davranacakları savunulmaktadır. Temsili bürokrasi, kamu kuruluşlarının yapısı ile hizmet edilen toplumun benzerlik göstermesine yönelik geliştirilmiş bir kavramdır. Kamu politikalarının belirlenmesi ve uygulanması noktalarında takdir yetkisine sahip bürokratların değer ve öncelikleri çok önemli olmakta ve bu noktada da toplumun değerlerini yansitan kişilerin bu görevlerde olmaları gerektiği vurgulanmaktadır (Andrews, Boyne, Meier, O’Toole ve Walker, 2005:491). Temsili bürokrasi taraftarlarına göre toplumun bütününü temsil kabiliyetine sahip bürokrasi sayesinde vatandaşın ihtiyaçları ve beklentileri daha iyi anlaşılabilecek, bu doğrultuda politikalar belirlenmesi ve uygulanması sağlanabilecektir. 1. TEMSILİ BÜROKRASİ Bürokrasi kavramının anlamı konusunda olumlu-olumsuz birçok tanım yapıldığı gibi farklı siyasi bakış açıları dolayısıyla önemi ve yapısı ile ilgili de değişik değerlendirilmelerde bulunulmuştur. Buna göre kimi çevreler bürokrasiyi demokratik hayatın vazgeçilmez bir unsuru ve bunun kamu sektörüne yansıması olarak değerlendirmektedir. Bunlara göre bürokrasi olmaksızın demokrasi gerçekleşemez veya var olamaz. 
Kimi siyasi çevrelere göre ise bürokrasi kamu sektöründe çalışanların güçleri ve egemenliklerini artırdığı için demokrasinin gerçekleşmesi önünde önemli bir engeldir ve var olduğu sürece demokrasi gerçekleşemeyecektir (Öztürk, 2017:73). Dolayısıyla hem demokrasinin yerleşebilmesi hem de bürokratların güçlerinin sınırlanması amacıyla temsili bürokrasi uygulamaları önemli bir araç olarak ortaya çıkmaktadır. Böylece demokrasi açısından bürokrasiden gelebilecek tehlikeler önlenebileceği gibi demokrasinin gelişimine bürokratik bir katkı da söz konusu olabilecektir. Bürokrasi-demokrasi ilişkisinde dengenin sağlanması, toplumdaki azınlık veya dezavantajlı tüm unsurların eşite yakın şekilde bürokraside yer alabilmelerinin sağlanması, bu noktada bürokrasinin olumsuz yönlerinin giderilebileceği düşünceleriyle "temsili bürokrasi” kavramı ortaya atılmıştır. İlk olarak 1944 y1lında Donald Kingsley tarafindan İngiltere için ardından 1946 y1lında Levitan ABD bürokratik sistemine alternatif olarak önermiştir (Clark, Ochs, ve Frazier, 2013:77). Kingsley temsili bürokrasi teorisini, kamu politikalarının uygulanması sürecinde atanmış yetkililerin geniş takdir yetkisiyle donanmış ve bu sebeple endişe duyulduğu bir dönemde ortaya atmıştır. Seçilmişler tarafından alınan kararların uygulanması sırasında sahip olunan bu geniş takdir yetkisiyle bürokratlar, politikaları önemli ölçüde etkileyebilme ve yönlendirebilmektedirler. Dolayısıyla bürokratların sahip olduğu bu geniş takdir yetkisi halka karşı sorumlu olmamaları sebebiyle demokratik ilke ve değerlerle de çatışmaktadır. Kingsley'e göre bürokratların sahip oldukları gücün dengesi ve kamuda demokratik değerlerin olması için temsil çok önemlidir. Kingsley’e göre kamu kurumlarında temsil herkesin sorumluluklarını tam olarak yerine getirmeleri açısından oldukça önemlidir (Grissom, Kern ve Rodriguez, 2015:186). Kingsley ve Levitan'ın ardından birçok bilim adamı da farklılıkları olan toplumlarda bürokratik yapılarda temsilin önemine vurgu yapmışlardır. Onlara göre ülkeler yönetsel teşkilatlarını oluştururken sahip olunan çeşitliliği yansıtmalıdırlar (Woo, 2015:12). Buradaki temel düşünce; kamu yöneticilerinin sosyal geçmişleri ve statülerinde var olan farklılıklardan yararlanarak farklı bakış açıları ortaya koymak, deneyimleri ve sosyalleşmelerine dayanarak hükümeti ve ortaya konulan politikaları daha duyarlı hale getirmek ve performansı artırmaktır (Clark, Ochs, ve Frazier, 2013:77). Temsili bürokrasi; bir toplumdaki bütün ekonomik sınıfların, dilsel-dinsel ve etnik grupların, kadın ve engelli gibi dezavantajlı kişilerin bürokraside sayılarıyla orantılı olarak temsil edilmesini ifade etmektedir. Bürokratik kademede bu şekilde bir temsilin gerçekleşmesi durumunda, bürokrasinin kırtasiyecilik, verimsizlik, hantallık, kötü yönetim, aşırı güç gibi olumsuz yönlerinin törpüleneceği ve toplumsal gruplar için endişe kaynağı olmaktan çıkacağı söylenmektedir (Öztürk, 2017: 255). Kavram, toplumların demografik yapısının bürokrasilerin demografik kompozisyonlarında yansıması gerektiği ve bu şekilde bürokratik karar alma mercilerinde bu farklı popülasyonların temsil edilebileceği üzerine kurgulanmıştır (Riccucci ve Saidel, 1997: 423). Temsili bürokrasi savunucularına göre bu yöntemle işbaşına gelmiş kamu sektörü çalışanları, toplumun bir nevi aynası olmakta ve halk ile daha güçlü bağlar kurabilmektedir. Dolayısıyla bürokratlar halkın talep ve beklentileri doğrultusunda kamu politikalarının belirlenmesi ve uygulanması konusunda daha duyarlı olacaklardır (Öztürk, 2017: 256). Bunlar farklı çıkar grupları, dil, din, etnik köken, cinsiyet veya sınıflara yönelik belli taahhütleri olan bireylerden oluşan temsili bürokrasilerin, büyük ölçüde ve daha kapsamlı politikalar üretebileceğini, bunu da bir öçlüde güvence altına alabileceğini savunurlar (Rehfuss,1986:454). İşe ulaşmada firsat eşitliği, katılım, demokrasi gibi değerler üzerine gelişen işgücünde etnik, renk, dil, din, kültürel çeşitliliğin bürokraside karş1lığ temsili bürokrasi olmuştur. Bu sayede bir ülkede ki işgücü rezervinin etkin bir şekilde yönetilebileceği, çeşitliliğin farklı bakış açıları yaratıp problem çözme yeteneklerini geliştireceği, devletin performansını artıracağ 1 savunulmaktadır (Clark, Ochs, ve Frazier, 2013:76). Pitkin ve Mosher temsili bürokrasi teorisini pasif ve aktif temsil şeklinde bir ayrıma tabi tutmuşlardır. Pasif temsil bürokrasinin, toplumun bileşenlerini demografik olarak nasıl yansıttığına ilişkindir (Clark, Ochs, ve Frazier, 2013:78). Mosher'e göre pasif temsil bürokrasinin hizmet ettiği nüfus ile aynı kökene sahip olmasıdır. Bu, etnik, dil, din, renk, cinsiyet gibi özellikler bakımından aynı kökenden olmayı anlatır. Pasif temsil bürokraside nüfusun genel yapısının veya azınlıkların temsil edilip edilmediği ile ilgilenmektedir (Wilkins ve Williams; 2005). Mosher pasif temsili bürokrasiyi 
toplumda var olan tüm sosyal grupların bürokraside olması ve dolayısıyla hizmet edilen toplumun demografik olarak bir bileşimi olarak tanımlamaktadır. Pasif temsili bürokrasi ile bir toplumda var olan bütün farklılıklar bürokraside görünür kılınacak, geniş bir kimlik algısı oluşturacak ve çeşitliliğin kabulüne hizmet edecek bu sayede de kamu hizmetlerinde meşruiyeti sağlayacaktır (Woo,215:13) Bir başka tanıma göre pasif temsili bürokrasi; bürokrasinin hizmet ettiği nüfus veya demografik yapı ile aynı kökenler üzerinde kurulu olmasıdır (Riccucci ve Saidel, 1997:423). Aynı demografik kökenlere bağlı olarak ortaya çıkan değerlerin, politikaların, kararların benzer kökenden olanlara dönüştürülebileceği üzerine kurgulanan ise aktif temsili bürokrasidir (Riccucci ve Saidel, 1997:423). Pitkin' e göre aktif temsil politika yapımını ve uygulamalarını temsilin ne kadar etkilediğine bakmaktadır. Aktif temsil teorisine göre bürokratlar temsil ettikleri gruplar adına harekete geçecek ve onların yararına faaliyetlerde bulunacaklardır (Wilkins ve Williams; 2005). Aktif temsil bürokratların görevleri sırasında hizmet ettikleri toplulukları ve toplulukları etkileyen kamu politikalarını savunmaktadır (Clark, Ochs, ve Frazier, 2013:78). Dolayısıyla aktif temsil bürokratların mensubu oldukları sosyal gruplara yönelik olarak gerçek ve önemli fayda sağlayacak veya artıracak hareketlerde bulunmalarıdır (Woo, 215:14). Bir bürokrat temsil ettiği bireylere yönelik olarak politik çıtılar üretebiliyorsa aktif temsili gerçekleştirmiş olur. Başka bir deyişle bürokraside aktif temsil, bürokratik iş gücü tarafından çeşitli grupların çıkarlarının politikalarda karşılanması ve uygulanmasıdır (Grissom, Kern ve Rodriguez, 2015:186). Ancak, bürokratik temsilin pasif veya aktif olması gerekip gerekmediği konusunda tam bir uzlaşma olduğu da söylenemez. Pasif temsilin, büyük ölçüde demografik yapı ve toplumdaki ilgi alanları ile ilgili olduğu ve dolayısıyla iktidara eşit erişimin sembolik taahhüdünü temsil ettiği buna karşın aktif temsilin ise bürokratların ait oldukları grupların üyeleri adına davranışları anlamına geldiği genel kabul görmektedir (Rehfuss, 1986:454). Temsili bürokrasi taraftarlarına göre teorinin kendisinden beklenilen faydayı sağlayabilmesi, etkinlik ve verimliliği artırabilmesi, talep ve beklentilere uygun politikaların yapılması ve uygulanması noktasında doğru çalışabilmesi için gerekli bir takım şartlar bulunmaktadır. Buna göre ilk olarak bürokratların belli kamu politikalarının belirlenmesi ve uygulanması aşamasında geniş bir takdir yetkisi olmalıdır. İkici koşul; politikalar belirlenirken ve uygulanırken hitap edeceği kesimin demografik yapısı dikkate alınmalıdır (Wilkins ve Williams; 2005). Bürokrasilerde temsili artırma konusunda ülkeler arasında farklı uygulama ve metotlara rastlanmaktadır. Personel sistemi içerisinde temsili artırmak, yönetim kadrolarında temsili artırmak, vatandaş katılımını artırmak gibi farklı yöntemler kullanılmaktadır. Metot ne olursa olsun bunların bürokratların hâkimiyetini bir şekilde sınırlandırdığ 1 için olumlu, etkinliklerini azalttığı için de olumsuz yönde eleştirilere uğramaktadır (Öztürk, 2017: 256). Ülkelerin sahip olduğu devlet biçimleri de esasında temsili bürokrasi uygulamaları üzerinde önemli etkiye sahiptir. Üniter sisteme sahip olan Türkiye gibi ülkelerde tek vatandaşlık söz konusu olduğu için hizmete alımlarda, terfi ve yükseltmelerde genellikle anayasalarda "Hizmete alınmada, görevin gerektirdiği niteliklerden başka hiçbir ayrım gözetilmez" şeklinde düzenlemelere gidilir (Bkz.1982 T.C. Anayasası md.70). $\mathrm{Bu}$ düzenlemelerde vatandaşların birbirleriyle eşit konumda oldukları ve aralarında hiçbir ayrımın yapılamayacağı şeklinde bir anlayış hâkimdir. Dolayısıyla bu anlayış ülkede yaşayan farklı etnik, mezhep veya kültürel gruplardan insanları eşit birer vatandaş olarak görmeye odaklanmaktadır. Ancak temsili bürokrasi sadece toplumsal farklılığı olan bireyler bakımından değil, engelli ve kadınlar bakımından da önem taşıyan unsurlar içermektedir. Bu nedenle kadın ve engelliler bakımından üniter sisteme sahip ülkelerde pozitif düzenlemelere gidilmesinin önünde bir engel yoktur. Nitekim Türkiye'de vatan hizmetinden kadınların muaf tutulması pozitif ayrımcılık olarak değerlendirilebilir. Benzer şekilde kanun önünde eşitliği düzenleyen Anayasanın 10. Maddesinin birinci paragrafı "Herkes, dil, ırk, renk, cinsiyet, siyasi düşünce, felsefi inanç, din, mezhep ve benzeri sebeplerle ayrım gözetilmeksizin kanun önünde eşittir” hükmünü getirmekte, bu maddenin ikinci ve üçüncü paragrafları ise kadınlara, çocuklara, yaşlılara, özürlülere, harp ve vazife şehitlerinin dul ve yetimleri ile malul ve gazilere yönelik pozitif ayrım yapılabileceğini hükme bağlamaktadır. Ülkemizde başta anayasa ve yasalarda olmak üzere hukuksal, toplumsal, ekonomik, siyasi, aile veya iş hayatında eşitlik veya 
dezavantajlı kişilere yönelik pozitif ayrımcılığı destekleyen birçok düzenleme yapılmıştır. Bu konuda yasal alt yapının özellikle son dönemlerde yapılan düzenlemelerle iyileştirildiği görülmekteyse de uygulama açısından gelişmiş ülkelere oranla çok gerilerde kalındığı bilinmektedir. Özellikle çalışma hayatında dezavantajlı kişilerin istihdam oranları dünyanın birçok gelişmiş ülkesinin gerisindedir. Devlet Personel Başkanlığı'nın açıkladığı verilere göre; kamuda çalışan kadın oranı \%37.98, erkek oranı \%62.02'dir. Bu da kamu sektöründe çalışan kadın sayısının erkeklerin hemen yarısı kadar olup, Kanada gibi gelişmiş ülkelere kıyasla oldukça kötü bir durumda olduğunun net göstergesidir. Ülkemizde engelli nüfusun kamuda çalıştırılma zorunluluğu olduğu için temsil kabiliyetleri bulunmaktadır. Ancak engelli çalışan sayısının cinsiyetlere göre dağılımı yine kadın engelli kişiler için oldukça kötüdür. Ülkemizde toplam engelli nüfusu içerisinde kadın engelli oranı \%52 ile erkeklerden fazladır. Kadın engelli oranının fazlalığına karşın Devlet Personel Başkanlığı verilerine göre kamuda çalışan toplam engelli içerisinde kadın engelli oranı \%24 erkek engelli çalışma oranı bunun yaklaşık üç katı \%76'dır (dpb.gov.tr). Bu da açıkça göstermektedir ki bu kişilere yönelik pozitif ayrımcılık yasal olarak düzenlemiş olsa da cinsiyetler açısından uygulamada daha dikkatli davranılması gerekmektedir. Federal sistemi benimseyen Kanada, Hindistan ve ABD gibi ülkelerde toplumsal farklılıkların bürokratik temsilde eşitlik yoluyla giderilmesi hususlarına daha fazla önem verilmekte ve buna uygun yasal düzenlemeler yapılmaktadır. Kanada Anayasası'nın 15. maddesi “Her birey, kanunun önünde eşittir ve özellikle ırk, ulusal veya etnik köken, renk, din, cinsiyet, yaş, zihinsel veya fiziksel engelleri temelinde ayrımcılık yapılmadan eşit koruma ve eşit haklara sahip olma hakkına sahiptir” hükmüyle herkesi için her türlü ayrımcılığı yasaklamıştır. Aynı maddede ele alınan pozitif ayrımcılık hükmüne göre bu eşitlik ilkesi "1rk, milliyet ya da etnik köken, renk, din, cinsiyet, yaş, zihinsel veya fiziksel nedenlerden dolayı dezavantajlı olan dezavantajlı bireylerin veya grupların koşullarının iyileştirilmesi amacına sahip olan herhangi bir kanunu, programı veya faaliyeti engellemez". Kanada'da eşitliğin kabulü veya ayrımcılığın yasaklanması sadece anayasada yer bulmamıştır. Kanada İnsan Hakları Yasası'na göre de “ırk, ulusal veya etnik köken, renk, din, yaş, cinsiyet, cinsel yönelim, cinsiyet kimliği veya ifadesi, medeni hal, aile durumu, genetik özellikler, fiziksel veya zihinsel engellilik üzerinden her türlü ayrımcılık yasaklanmıştır. Aynı yasanın 7. maddesinde iş ve çalışma hayatına ilişkin olarak da her türlü ayrımcılık yasaklanmıştır. Buna göre "Herhangi bir bireyi istihdam etmeyi veya kullanmaya devam etmeyi reddetmek veya istihdam sırasında, bir çalışanla ilgili olarak yasaklı bir ayrımcılık yapmak, doğrudan veya dolaylı olarak ayrımcı bir uygulamadır ve yasaktır". Ayrıca "Herhangi bir istihdam için yasaklanmış bir ayrımcılık temeline dayanan herhangi bir sınırlama, şartname veya tercih ifade eden veya ima eden bir başvuru formunu kullanmak veya dağıtmak, herhangi bir ilan yayınlamak veya herhangi bir yazılı veya sözlü soruşturma yapmak yasaktır". Hindistan Anayasası'nın 15. maddesine göre "Devlet, vatandaşları arasında din, ırk, kast, cinsiyet, doğum yeri veya herhangi biri dolayısıyla ayrımcılık yapmamalıdır. Halka açı yerlerin kullanımında din, ırk, kast, cinsiyet, doğum yeri veya herhangi biri dolayısıyla kısıtlama, koşul veya şart getirilemez. Ancak bu kadınlar ve çocuklar için özel hükümler getirilmesini önlemez”. Anayasa'nın 16. maddesinde ise kamu istihdamında firsat eşitliğini sağlamaya yönelik olarak bir düzenleme yapılmıştır. Buna göre; " Bütün vatandaşlar devlet çatısı altındaki herhangi işyerinde istihdam veya atama konusunda eşit firsatlara sahip olmalıdır. Hiçbir vatandaş din, 1rk, kast, cinsiyet, doğum yeri, ikamet yeri veya herhangi biri dolayısıyla devlet çatısı altında çalışan işyerlerinde ayrımcı uygulamaya maruz kalmamalıdır”. Madde ile istihdam olunacak alanın nitelik ve yeterliliği devlet tarafından belirlenecek ve buna uygun olan herkesin istihdam veya ataması yapılabilecektir. Hindistan'da eşit istihdam firsatı prensipleri işlere erişim, istihdam koşulları, işyerinde ilişkiler, performans değerlendirmesi, eğitim ve kariyer gelişimi gibi istihdam ile ilgili her alanda geçerlidir. Federal sistemi benimseyen bir diğer ülke ABD’nde de istihdamda firsat eşitliği konusunda benzer şekilde yasal düzenlemeler yapılmış ve kamu- özel sektör ayrımı yapılmaksızın her türlü ayrımcılık yasaklanmıştır. 1964 tarihli Sivil Haklar Yasası'nın 7. bölümünde Eşit İstihdam Fırsatı başlığıyla ırk, renk, ulusal köken, din veya cinsiyet temeline istihdamda ayrımcılık yasaklanmış, yasayı uygulamak üzere bağımsız 
bir düzenleyici kurum olarak Eşit İstihdam Fırsat Komisyonu (EEOC) kurulmuştur. 1972 tarihli Eşit İstihdam Yasası ile Komisyona ırk, renk, din, ulusal köken veya cinsiyete dayalı bir ayrımcılık yapıldığına dair makul bir neden olduğunda federal mahkemelerde dava açma hakkı tanınmıştır. Yine 1990 yılında kamu ve özel sektörde engelli kişilere yönelik istihdamda ayrımcıllı̆ı yasaklayan Engelli Amerikalılar Yasası kabul edilmiştir.

\section{KANADA'DA İSTIHDAM EŞiTLIĞİ VE KAMU HIZMETİ İSTIHDAM YASASI}

Kanada'da istihdamda çeşitliliğin artırılması, kucaklanması ve işgücüne daha fazla katılımlarının sağlanması için 1995 yılında İstihdam Eşitliği Yasası (Employment Equity ACT) yayımlanmıştır. Yasanın amacının işyerlerinde eşitliğin sağlanması olduğu ve böylece hiç kimsenin yetenekleri, liyakatları ve faydaları dışında başka bir sebeple çalışma olanaklarının ellerinden alınamayacağı belirtilmiştir. Yasa özel veya kamu sektöründe çalışacak kadın, engelli, Aborjin ve azınlık mensuplarının eşit istihdam koşullarına sahip olması hedefindedir. Yasaya göre bu hedefin gerçekleştirilebilmesi için kadınların istihdam alanında yaşadıkları dezavantajlı koşulların düzeltilmesi, Aborjin halklarının, engelli kişilerin ve diğer azınlık mensuplarının istihdam eşitliklerinin sağlanması, yaşanılan sıkıntıların tespit edilmesi, giderilmesi ve bunun ötesinde özel önlemler alınması gerekmektedir. Yasaya göre işveren olarak özel veya kamu sektörü ayrımı yapılmaksızın işveren sorumlulukları başlığı altında bir takım görev ve yükümlülükler tanımlanmıştır. Buna göre her işverenin; 1. Yasalarca izin verilmeyen istihdam sistemleri, politikaları ve uygulamalardan kaynaklanan, belirlenmiş gruplardaki bireylere yönelik istihdam engellerini tespit etmek ve bunları ortadan kaldırmak, 2 . Kanadalı iş gücünün içerisinde belirtilmiş kişilerin, her meslek grubunda makul derecede temsil edilebilmelerini sağlamak üzere pozitif politikalar ve uygulamalar oluşturmak, 3. Belirtilen azınlık ve dezavantajlı gruplara yönelik pozitif politika ve uygulamalar oluşturmak yükümlülügü bulunmaktadır. Ancak yasaya göre işverene istihdam hakkının uygulanması noktasında yüklenen bu yükümlülükler; işverene gereksiz bir maliyet veya zarar vermesi halinde, işin niteliklerine uygun olmayan kişilerin işe alımını zorlayacak nitelikte veya iş gücünde yeni pozisyonlar açılmasının zorlanması şeklinde yorumlanmamalıdır (lawslois.justice.gc.ca/). Yasaya göre istihdam hakkının uygulanması amacıyla ayrıca her işverenin,

1. Kendi işyeri içerisinde her bir meslek grubunda belirlenen gruplardaki kişilerin yetersiz temsil derecesini belirlemek amacıyla, düzenlemelere uygun olarak, işgücü hakkında bilgi toplaması ve analizini yapması,

2. Belirlenmiş gruplardaki kişilere karşı iş engellerini tespit etmek için istihdam sistemlerini, politikalarını ve uygulamalarını, düzenlemelere uygun olarak gözden geçirmesi,

3. İşverenler işgücü potansiyelinin tespit edilmesi ve bunun istihdam hakkının uygulanmasına yansımasını izlemek için istihdam eşitliği planı yapması, kayıtlarını tutması ve bunu dönemsel olarak ilgili birimlere rapor şeklinde sunması gerekmektedir. İşverenler tarafından İstihdamda Eşitlik Komisyonu'na sunulan bu dönemsel raporlar Komisyon tarafından yasalara ve gerçekliğe uygunlukları açısından değerlendirilmektedir. Bu değerlendirmeler sonucunda yasalara veya gerçekliğe aykırılık tespit edilmesi halinde yargı yolu açık olmak üzere gerekli para cezaları verilmektedir (laws-lois.justice.gc.ca/). Yasaya göre bir işverenin Aborjin halklarının çıkarlarını teşvik etmek veya bunlara hizmet etmek üzere faaliyet gösterdiği alanlarda bu yasaya bakılmaksızın, yalnızca Aborjin halklarını istihdam edebilir veya tercih edebilir. Bu madde Kanada İnsan Hakları Yasası kapsamında Aborjin halklarına yönelik pozitif ayrımcı bir uygulamadır ve İstihdamda Eşitlik Yasasına aykırı sayılmamaktadır (laws-lois.justice.gc.ca/). Kanada'da çalışma hayatında azınlık veya dezavantajlı gruplara yönelik olarak tek ve özel düzenleme İstihdamda Eşitlik Yasası değildir. Konu ile ilgili bir diğer düzenleme kamu sektöründe istihdama yönelik Kamu Hizmeti İstihdam Yasasıdır (Public Service Employment Act). Yasa ilk olarak 1985 tarihinde yayımlanmış ancak yasada 2003 tarihinde eşitlik ve liyakat 
konularının altının özenle çizildiği yeni ve köklü düzenleme yapılmıştır. Yasaya göre; "kamu hizmeti sektörü Kanada'nın inşasında önemli katkılarda bulunmuş, en yüksek kalitede kamu hizmeti sunmuş ve gelecekte de bunu yapmaya devam edecektir. Mükemmel ve en kaliteli hizmet için çalışan kamu sektörü, Kanada'nın çeşitliliğini temsil eden, kamuya dürüstlükle ve kendi dilleriyle hizmet edebilen bir kamu hizmeti idealiyle Kanada'ya kazandırmaya devam edecektir. Ayrıca çalışanları ülkenin genel profilini yansıtan Kanada kamu sektörü, ülke için eşsiz bir kaynak, arka plan, beceri ve meslek yelpazesi sunmaktadır. Bu itibarla Kanada kamu sektörü, liyakat ve eşitlik temeline dayanan bir kamu hizmetinden yararlanmaya devam edecektir” (lawslois.justice.gc.ca/). Kamu Hizmeti İstihdam Yasası'nın istihdamda eşitlik konularında birçok maddesinde İstihdamda Eşitlik Yasası'na atıflar yapılmış ve konu üzerinde ki hassasiyet özellikle vurgulanmıştır. Kanada'da kadınlar, Aborjin halkları, engelliler ve azınlık mensubu kişilerin belirtilen yasalar dâhilinde istihdamda eşit firsatlara sahip olmaları, görevin gerektirdiği liyakat ve yetenek dışında herhangi ayrıma tabi tutulmalarının engellenmesi ve denetlenmesi konularında görev yapmak üzere İstihdam Eşitliği Komisyonu kurulmuştur. Komisyon, Kanada Hazine Kurulu Sekretaryası, Kanada Kamu Hizmeti Komisyonu ve diğer departman temsilcilerinden oluşmaktadır. Komisyon İstihdam Eşitliği Yasası kapsamında belirlenen gruplara yönelik uygulanacak kamu politikalarının belirlenmesi, geliştirilmesi konularında uzman ve sorumluluğu olan diğer ortakları ve gençlik temsilcilerini de işbirliği yapmaya davet edebilir. İstihdam Eşitliği Komisyonu, kamuda görev yapan kişiler arasında istihdam eşitliği ve çeşitliliğe ilişkin çalışmalar yapmanın yanı sıra federal kamu hizmetinde ortaya çıkan politikalar ve uygulamalar hakkında hükümete tavsiye ve önerilerde bulunur. $\mathrm{Bu}$ komisyon altında ilgili grupların temsilini denetlemek üzere daireler oluşturulmuştur. Aborjin halkların istihdamda eşit temsilini sağlamak ve denetlemek üzere Aborjin Halkları Sandalyeler Dairesi görevlendirilmiştir. Daire, Aborjin halkları için işe alım, işe devam ve kalkınma olmak üzere üç temel alan üzerinde çalışarak onların sağlıklı bir işyeri ve çalışma ortamına kavuşmalarına odaklanmaktadır. Bu daire Aborjin tarihi ve kültürü konusunda bilinçlendirilmesi, kamu hizmetinde temsilinin sağlanmasını gerçekleştirmek üzere Kanada Kamu Hizmeti Okulu aracılığıyla gerekli eğitimlerin alınması, işe alımları, kariyer ve gelişmelerinin izlenmesi, deneyimlerinin paylaşılması için çalışmalar yapmakta, raporlar hazırlamaktadır. Bu sayede Aborjin liderlik gelişimine rehberlik etmekte, iletişimlerini sağlamakta ve bunu tesis etme konularında ortak çalışmalar yapılmasına aracılık etmekte ve öneriler sunmaktadır. Bu kapsamda Yerli ve Kuzey İşler Kanada Aborjin Liderlik Gelişimi Girişimi, Ulusal Savunmada Aborjin Rehber Pilot Projesi gibi girişimlerde bulunulmuş, bu gruplara özel firsatlar sunulmuştur (canada.ca). Yine engelli kişilerin istihdamda temsilini denetlemek ve yasalara uygunluğunu sağlamak üzere Engelli Kişiler Sandalye Dairesi görevlendirilmiştir. Daire ayrıca engelli kişilerin mevcut mobil uygulamaları, ürün ve hizmetleri gibi teknolojiye erişimlerinin önündeki sorunların çözümü için de faaliyetlerde bulunmakta, insiyatifler almaktadır. Azınlık mensupları ile görevli Azınlık Sandalyeleri Daireleri ise diğer gruplar gibi azınlık mensuplarına da kapsayıcı ve saygılı bir iş ortamının teşvik edilmesinin sağlanması, kariyer gelişimin teşvik edilmesine çalışmaktadır. Daire çeşitliliği kucaklayan, taciz ve ırk ayrımcılığını engelleyen, kapsayıcı işyeri kültürünü egemen kılmak, azınlık üyelerinin dil eğitimi fırsatlarına erişimi ile ilgili devam eden sorunlarını çözmek, kendilerini geliştirmelerine olanak sağlamak amacındadır (laws-lois.justice.gc.ca/).

\section{KANADA KAMU YÖNETIMI’NDE TEMSIL}

Kanada’nın nüfusu son verilere göre 37.120.804. Bunun 18.704.049’u (\%50.4) kadın nüfustur (countrymeters). Nüfusun \%16'dan fazlası yaklaşık 5.5 milyonu engelli kişilerdir (easterseals.ca). Yine nüfusun yaklaşık olarak \%5'i kendini Aborjin olarak nitelendirirken, \%20'den fazlası azınlık mensubu kişidir. Azınlık nüfusun büyük çoğunluğu Güney Asya, Çin ve siyahlar ((\%62), Filipin, Japon, Kore, Latin Amerika ve Araplardan oluşmaktadır (12.statcan.gc.ca). Bu çok kültürlü yapının kamuda da eşit oranlı temsil edilmesi konusunda 
anılan yasal düzenlemeler yapılmakla kalmamış uygulamaya da özel önem verilmiştir. Bu konuda denetimler ve değerlendirmeler yapılmış, dönemsel olarak raporlar sunulmuştur. Kanada'da hemen her yıl kamuda çalışan ve bunların demografik yapı analiz raporları açıklanmaktadır. Bu raporların ortaya koyduğu veriler 1şığında kamuda çalışanlar içerisinde temsil konusunda ayrıntılı verilere ve karşılaştırmalı bilgilere sahip olabilmekteyiz. Raporlar sonucunda Kanada kamu yönetiminde kadın, engelli, Aborjin halkları ve azınlıkların temsiline ilişkin verilere ortaya konmaktadır. Bu veriler ışığında gerçek durum tespiti yapılması, sorunlara çözümler getirilmesi sağlanmaya çalışılmıştır. Kanada'da kamusal yapı temel kamu yönetimi birimleri ve diğer ajans ve ofisler olmak üzere ikiye ayrılmıştır. Eğitim, sağlık, güvenlik, dış politika gibi alanlarda hizmet veren birimler temel kamu yönetimi birimleri olarak adlandırılmaktadır. Enerji, gaz, gıda, ilaç denetim ve gelişimi ajansları, bilim ve enerji araştırma kurulları, istatistik kurumu gibi ilgili ve bağlı kuruluşlar da diğer ajans veya ofis olarak adlandırılmaktadır (canada.ca). Kanada'da kamuda çalışanların toplam sayısı 31 Mart 2017 itibariyle 262.696'dır. Bunların 199.691'i 66 temel kamu yönetimi kurumunda, 63.005'i de diğer ayrı ajans ve ofislerde çalışmaktadır. Kamuda çalışanların \% 41.1'i Ulusal Başkent Bölgesi'nde, \%58.9'u diğer bölgelerde çalışmaktadır (canada.ca). 2017 yılında açıklanan verilere göre kamuda çalışanların \%70.8'i İngilizceyi ilk resmi dil olarak belirtirlerken, \%29.2'si Fransızcayı ilk resmi dilleri olarak belirtmişlerdir. Bu oran 2000 y1lı verileri ile karşılaştırıldığında \%70.3 İngilizce, \%29.7 Fransızca olarak tespit edilmiş ve anlamlı bir değişim olmadığı görülmektedir. 2018 yılında yayımlanan ve son 10 yıl içerisinde istihdamda eşitliği gösteren Kanada Kamu Hizmetinde İstihdam Eşitliği Raporu'na göre; istihdam eşitliği kamu hizmetinin temelidir ve işgücünde çeşitlilik Kanada Hükümeti'nin önceliği olmaya devam etmektedir. İstihdam Eşitliği Yasası'nın ardından kadınlar, Aborjin halkları, engelli kişiler ve azınlık mensubu kişilerin istihdamda temsili konusunda önemli artışlar yaşandığ 1 belirtilmiş ve bu başarıların devam ettirilmesi gerektiğinin altı önemle çizilmiştir. İşgücünün çeşitlenmesi, güçlendirilmesi, herkesin potansiyelini ortaya koyabilmesi toplumsal saygı ve kaynaşma kültürünün gelişmesine de katkıda bulunmaktadır. Bu rapor aynı zamanda işyerlerinde pozitif uygulamaların takip edilmesi, bu konuda özveri ile çalışan herkese hak ettikleri değerin verilmesi ve işe getirilen farklı bakış açılarının geliştirilmesine katkıda bulunmaktadır. Rapora göre ilgili grupların kamu yönetiminde temsili konusunda bazı departmanlar ve meslek gruplarında boşluklar bulunsa da önemli bir temsile ulaşılmıştır. Tespit edilen boşlukların doldurulması konusunda çabaların devam etmesi gerektiği ayrıca vurgulanmıştır (canada.ca). Rapor sonucunda kamu hizmetlerinde "Birçok Ses, Tek Akıl”" stratejisi ve Federal Erişilebilirlik Stratejisi Eylem Planı oluşturulmuş ve devletin durumuna yeni bir bakış açısı sağlamıştır. Buna göre kamu hizmetinde çeşitlilik ve herkesin birlikte sürece dahil olması federal kamu hizmetinde ilerlemenin devam etmesi için bundan sonraki yol haritasının bir parçası olacaktır. Bundan sonraki süreçte de güvenli, sağlıklı, çeşitli ve kapsayıcı departman ve kurumların oluşturulması öncelikli hedef olmaya devam edecektir. Kamu hizmetlerinde elde edilen başarının sürdürülebilir olması istihdamda eşitlik ve çeşitliliğin işbirliği ile devam etmesine bağlanmıştır (canada.ca). 
Grafik 1: Yıllara göre Kamuda Toplam Çalışan Sayısının Cinsiyetler Açısından Dengesi

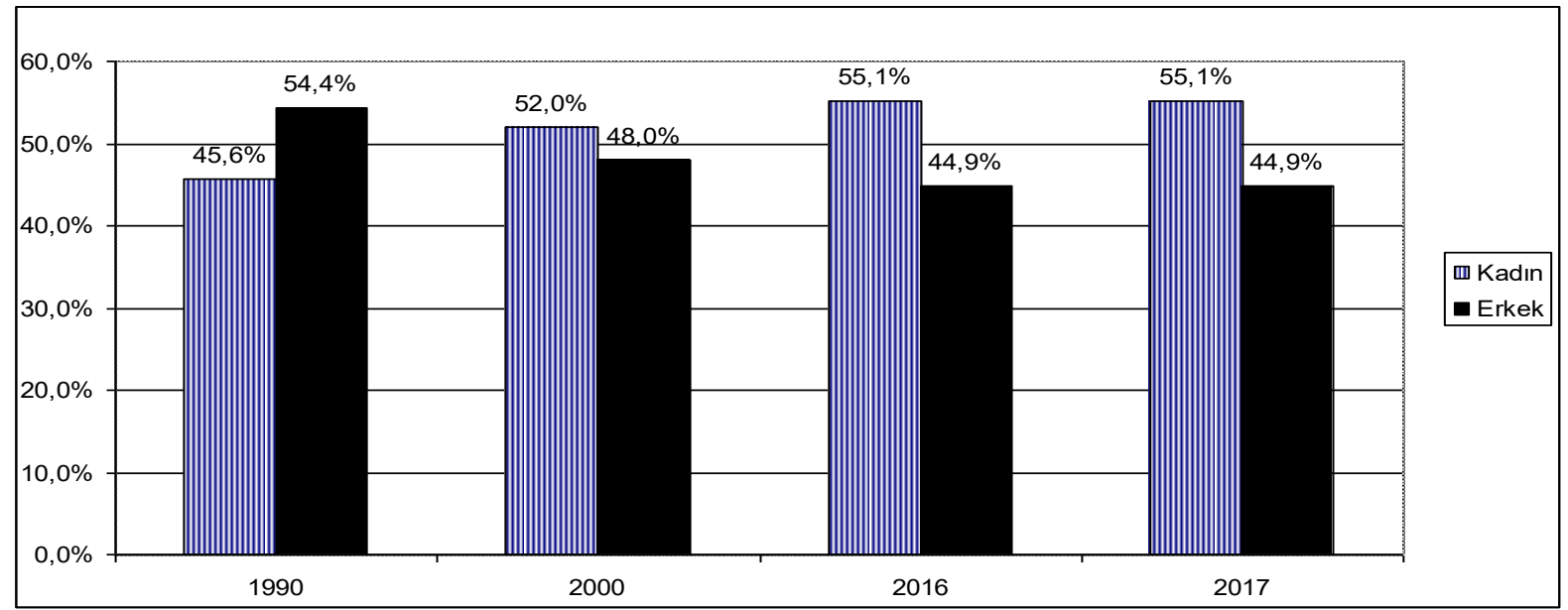

Kaynak : https://www.canada.ca/content/dam/tbs-sct/documents/reports/eepsfy-emefp/2017/eepsfy-emefpeng.pdf 13.08.2018

Kamuda çalışan sayısının cinsiyetler açısından dengesine ilişkin açıklanan bilgilere göre 1990'lı yıllarda erkekler lehine bir durum bulunmaktadır. Ancak 2000'li yıllardan sonra bu dengenin kadınlar lehine değiştiği, son 10 yıl içerisinde ise kadın-erkek temsil dengesinde anlamlı bir değişimin olmadığı görülmektedir.

Federal kamu hizmetinde 2017 Mart sonu itibariyle toplam 6,480 yönetici bulunmaktadır. Yönetici sayısında ki artışın sebebi federal kamu hizmetinde son 10 yıllık dönemde görülen \%24'lik artıştır. Federal kamu hizmetinde yaşanan artışa paralel olarak kamuda çalışan sayısı da artmıştır. Kamuda çalışan kadın temsilinde kadınlar lehine olan durum yönetici kadın sayısında da yükselişe sebep olmuştur. 1990 yılında \%14,7 olan yönetici kadın sayısı, 2000 yılında \%28'e, 2016 yılında \%46,5'e yükselmiştir. Bu anlamlı artış 2017 yılında da devam etmiş \%47'ye yükselmiştir (canada.ca). Cinsiyetler açısından denge oluşturulması temsil açısından dengeye kavuşmasına katkıda bulunurken, eşitlik konusunda zorlukların ortaya konması ve çözümlerin geliştirilmesi için oldukça önemli bir göstergedir.

Kanada Hazine Kurulu tarafından Mart 2006 - Mart 2016 yılları arasında temel kamu yönetimi birimlerinde çalışan kişiler arasında kadın, engelli, Aborjin halkı ve azınlıkların temsillerine ilişkin İstihdam Eşitliği Raporu yayınlanmıştır. Bu raporda açılanan verilere 2016 yılı verilerine göre temel kamu yönetimi birimlerinde çalışan toplam 181.674 kişi İstihdam Eşitliği Yasası kapsamında ele alınmıştır (canada.ca). Rapor, temel kamu yönetimi birimlerinde toplam çalışan sayısının azınlık, engelli ve Aborjin halkları açısından cinsiyetler dengesinin yanı sıra temsillerine ilişkin ayrıntılı bilgiler de içermektedir. 
Grafik 2: Cinsiyet Açısından İstihdam Dengesi

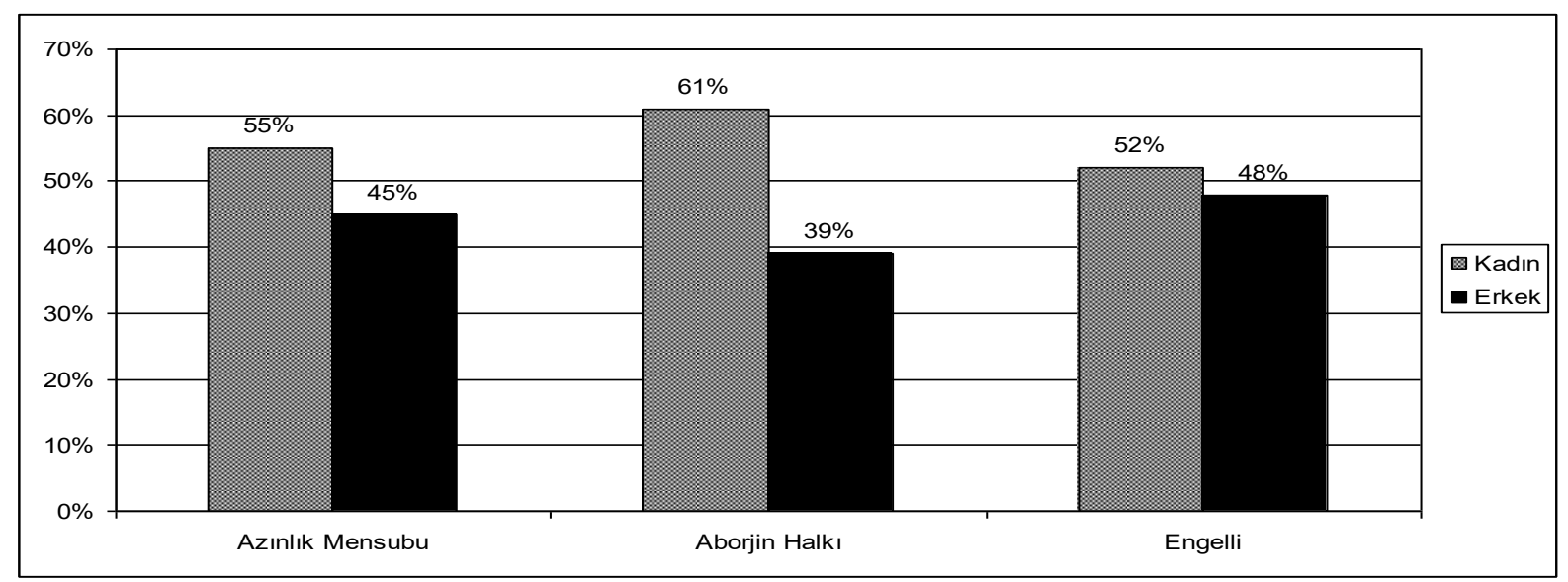

Kaynak : https://www.canada.ca/content/dam/tbs-sct/documents/reports/eepsfy-emefp/2017/eepsfy-emefpeng.pdf 13.08.2018

Grafik 2'de görüldüğü üzere cinsiyet dengesi açısından en büyük fark Aborjin halkı kadın-erkek çalışan grubu arasindadir (canada.ca).

Grafik 3: Kamu Yönetimi İstihdam Temsil Oranları

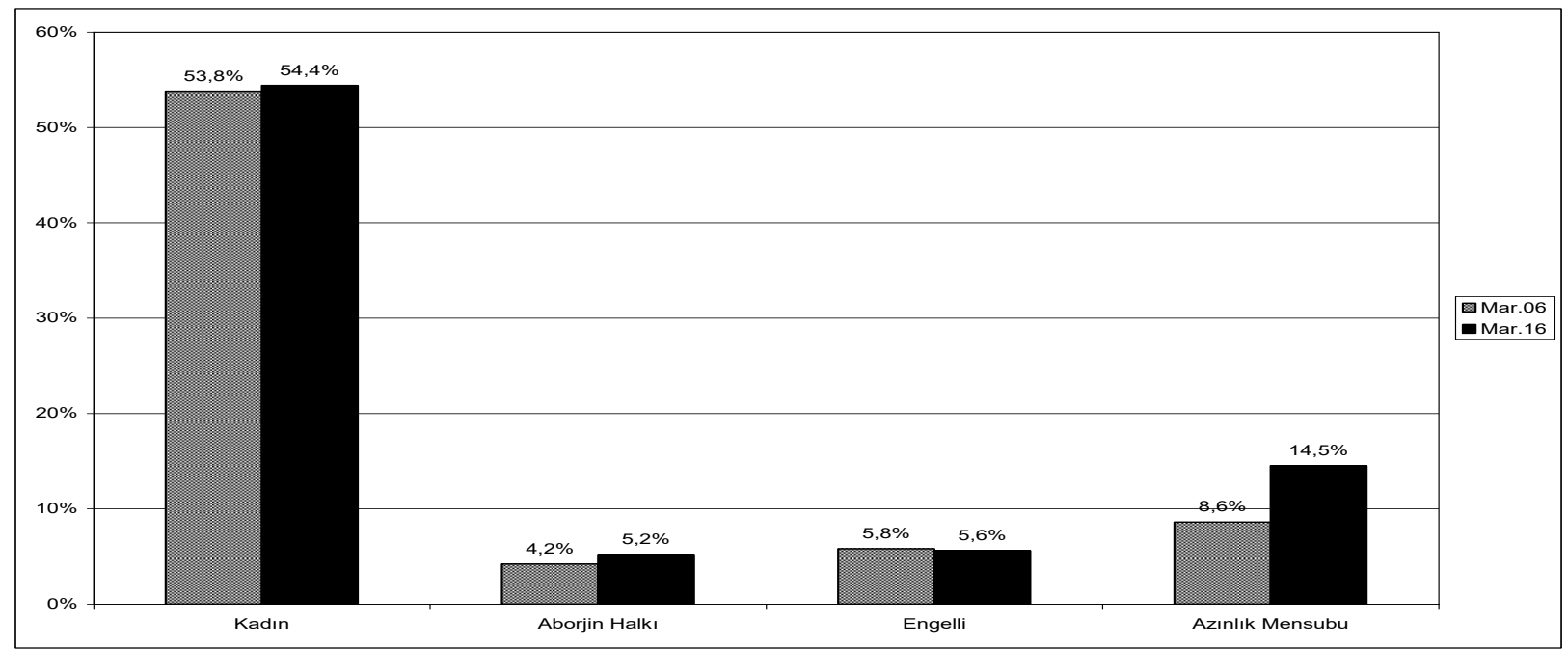

Kaynak : https://www.canada.ca/content/dam/tbs-sct/documents/reports/eepsfy-emefp/2017/eepsfy-emefpeng.pdf 13.08.2018

Raporun ortaya koyduğu veriler 1şığında Grafik 3'de görüldügüü üzere Mart 2006- Mart 2016 y1lları arasında toplam kamu çalışanı içerisinde kadın nüfusun, Aborjin halkın ve azınlık mensubu kesimin temsil oranlarının artış, buna karşın engelli nüfusun temsil oranın azalış eğiliminde olduğu görülmektedir.

İstihdam Eşitliği Raporu'na göre yönetici kademede engelli kişilerin temsil oranları iyi seviyelerde olmasına karşın kadınlar, Aborjin halklar ve azınlıkların temsil oranları ideal düzeyde değildir. Kanada kamu sektöründe 2011 yılında toplam çalışan sayısı 282.352 iken 2017 yılında yaklaşı \%10.7 (262.696) gerilemiştir (canada.ca). Çalışan sayısında yaşanan bu düşüş temsilde de aşağı yönlü bir harekete sebep olmuştur. Buna 
göre; kamuda çalışan kadın oranında \% 11, engelli kişilerde \% 11.4, Aborjin halklarında ise \%1.3'lük bir gerileme olmuştur (canada.ca).

1999 yılından bu yana 3 yılda bir federal kamu hizmeti çalışanlarının işyerlerine yönelik görüşlerini ölçmek üzere Kamu Hizmeti Çalışanları Anketi yapılmaktadır. Anket; kamu kurumlarının insan kaynakları ve personel yönetimi uygulamalarının durumunu izleme, belirleme, sorunlarını ortaya koyma ve çözüm için eylem planlarını geliştirme olanağı sunmaktadır. 2017 yılında yapılan anket sonuçları; kariyer gelişimi, yetkilendirme, örgüt performansı, çalışan katılımı ve üst düzey yönetim açlarından olumlu gelişmeler olduğunu ortaya koymuştur. 2018 yılı itibariyle üç yılda bir yapılan anketin daha sık yapılmasına karar verilmiştir. 2018 Kamu Hizmeti Çalışan Anketi, 20 Ağustos - 28 Eylül 2018 arasında gerçekleştirilecektir. Anket, Kanada'nın Hazine Bakanlığı Genel Müdür Yardımcılığı Ofisi tarafından yönetilecektir. Bu kapsamlı anket ile federal hükümet çalışanlarının kurumsal bağlılık, liderlik, işgücü, işyeri, iş yeri refahı ve tazminat hakkındaki düşüncelerini ölçülecektir. Anket sonuçları Şubat 2019 itibariyle ilan edilecektir. Anket sonucunda ortaya konan verileri çalışanlarıyla birlikte tartışmak üzere ilgili kurumlar davet edilecektir. Bu sayede sorunlara tüm paydaşların katılımıyla ortak çözüm önerileri geliştirilecektir. Anket ayrıca Yönetim Sorumluluk Değerlendirmeleri bağlamında yöneticilerin de performansına ilişkin sonuçlar ortaya koyacaktır (canada.ca).

\section{SONUÇ}

Temsili bürokrasi kavramı nüfusun temsili (pasif) ya da karar verme sürecini geniş bir yelpazenin etkilemesinin (aktif) garantisidir. Ancak kavramın temel varsayımı bürokratların toplumsal yapının bir benzeri veya yansıması olması durumunda, alınacak karar ve uygulamalarda kamuoyunun genel beklenti ve taleplerine uygun, onu karşılar nitelikte olmasıdır (Rehfuss, 1986:455). Kısaca demokrasinin gerçekleşebilmesi ve halkın tümünün kamusal kararlar üzerinde söz sahibi olabilmesi için temsili bürokrasinin çizdiği çerçeveye göre şekillendirilmiş insan kaynakları yönetimi ve personel politikalarına ihtiyaç duyulmaktadır ve bu yönde yapılacak düzenlemeler de ülkelerin gelişmişlik göstergelerinden biri olacaktır (Şahin, 2016:235).

Çalışmada ülkelerin yönetim sistemlerinin de bürokraside temsil konusunda önemli bir unsur olduğu ortaya konmuştur. Üniter sisteme sahip Türkiye'de konu daha çok istihdamda kadın, engelli, şehit yakını ve gazilere yönelik özel düzenlemelerle ele alınmaktadır. Buna karşın federal sisteme sahip Kanada gibi ülkelerde ise ırk, din, dil, renk veya cinsiyet gibi unsurlar noktasında farklılıkları olan kişilere eşit fırsat yaratılması noktasında ele alınmaktadır. Bu itibarla temsili bürokrasinin kavram ve uygulama olarak federal ülkelerde daha iyi karşılık bulduğu söylenebilir. Ancak bu üniter devlet modellerinde istihdamda firsat eşitliğinin yaratılması, kamu-özel sektör ayrımı yapılmaksızın vatandaşların işe almada işin niteliklerinden başka herhangi ayrımcılığa maruz kalmalarının önünde engel değildir.

Kanada istihdamda firsat eşitliğinin sağlanması ve ayrımcılıkla mücadele konusunda gerekli yasal düzenlemeleri yapmanın yanı sıra bu düzenlemelere uyulup uyulmadığını raporlar ve veriler aracılığıyla denetlemekte, çıkan sonuçlara göre gerekli cezai takibatları yapmaktadır. Ayrıca yapılan yasal düzenlemeler sorunları ortaya koymakla kalmamakta gerekli çözüm önerilerini ve iyileştirmeleri desteklemektedir. Ortaya çıkan sonuçlar ışığında kadınlar, engelliler, Aborjin halklar ve azınlıklar açısından eksik temsil olan bölüm, birim veya meslekler konusunda sorunları giderici çalışmalar da yapılmaktadır. Örneğin yönetici kadrolarında yaşanan eksik temsil konusunda Aborjin liderlik girişimleri yapılmakta ve böylece kamu yönetiminde gerekli yöneticilerin temsil eksikliğini giderecek şekilde yetiştirilmesi hedeflenmektedir.

Hiç şüphesiz kamu bürokratik kademelerinde yer alacak kişiler açısından toplumun yansıması ve temsil edilmesi ihtiyaç ve beklentilere cevap verebilme açısından önemlidir. Ancak bürokrasilerde azınlıkların veya dezavantajları olan kesimlerin eşit ve orantılı temsili kamu hizmetlerinde etkinlik ve verimliliğin artırılmasında 
tek başına etkili olamamaktadır. Kamu hizmetlerinde beklenen faydanın sağlanması, etkinlik ve verimliliğin artırılması, kamu yararı amacının azami şeklide gerçekleştirilmesi açısından işe alım ve yükselmelerde görevin gerektirdiği liyakat, yetenek, bilgi dışında herhangi bir unsura bakılmaması, rengi, dili, dini, etnik kökeni, cinsiyeti veya engeli dolayısıyla kişilere negatif yönde ayırımcılık yapılmaması gerekmektedir. Tabiyeti, cinsiyeti, yaşam tarzı, siyasal düşüncesi gibi unsurlar hariç tutularak işe uygun ve işin gerektirdiği liyakata sahip kişiler işe alınmalıdır. 


\section{KAYNAKÇA}

Andrews, R., Boyne, G. A., Meier, K, J., O’Toole Jr. L. J. and Walker, R. M. (2005), Representative Bureaucracy, Organizational Strategy, and Public Service Performance: An Empirical Analysis of English Local Government, Journal of Public Administration Research and Theory, JPART 15:489-504.

Altunok, H. ve Gedikkaya, F.G. (2016), Kamu Politikaları Ansiklopedisi, Nobel Yayınları, Ankara.

Bradbury, M. D. and Kellough, J. E. (2011), Representative Bureaucracy: Assessing the Evidence on Active Representation, The American Review of Public Administration 41(2) $157 \quad-167$ sagepub.com/journalsPermissions.nav DOI:10.1177/0275074010367823

https://www.researchgate.net/publication/240702914_Representative_Bureaucracy_Assessing_the_Evidence _on_Active_Representation (09.08.2018).

Clark, R. C., Ochs, H. A. and Frazier, M. (2013), Representative Bureaucracy: The Politics of Access to Policy Making Positions in the Federal Executive Service, Public Personnel Management 42(1) 75-89 sagepub.com/journalsPermissions.nav DOI: 10.1177/0091026013484570 ppm.sagepub.com (10.08.2018)

Eryılmaz, Bilal (2017), Kamu Yönetimi Düşünceler, Yapılar, Fonksiyonlar, Politikalar, Umuttepe Yayınları, İzmit-Kocaeli.

Grissom J. A., Kern, E. C. and Rodriguez, L. A., (2015), The "Representative Bureaucracy" in Education: Educator Workforce Diversity, Policy Outputs, and Outcomes for Disadvantaged Students, Educational Researcher, Vol. 44 No. 3, pp. 185-192, DOI: 10.3102/0013189X15580102.

Rehfuss, J. A. (1986), A Representative Bureaucracy? Women and Minority Executives in California Career Service Source: Public Administration Review, Vol. 46, No. 5 ( Sep. - Oct., 1986), pp. 454-460 Published by: Wiley on behalf of the American Society for Public Administration Stable URL: http://www.jstor.org/stable/975785 (11.08.2018) .

Riccucci N. M and Saidel J. R. (1997), The Representativeness of State- Level Bureaucratic Leaders: A Missing Piece of theRepresentative Bureaucracy Puzzle Source: Public Administration Review, Vol. 57, No. 5 (Sep. - Oct., 1997), pp. 423-430 Published by: Wiley on behalf of the American Society for Public Administration Stable URL: http://www.jstor.org/stable/3109988 (11.08.2018) .

Öztürk, Namık Kemal (2017), Bürokrasi-Siyaset İlişkileri ve Türkiye, Siyasal Kitabevi, Ankara.

Şahin, B. (2016), Kamu Personel Sisteminde İşe Girme Ve Yükselmede Çağdaş Liyakat Kavramları, Ç.Ü. Sosyal Bilimler Enstitüsü Dergisi, Cilt 25, Sayı 1, 2016, Sayfa 231-242 http://dergipark.gov.tr/download/article-file/360274 (12.08.2018).

Wilkins, M. V. and Williams, B. N. (2005), Black or Blue: Racial Profiling and Representative Bureaucracy, Prepared for presentation at the 8th Public Management Research Conference, September 29th - October 2nd, 2005 in Los Angeles, California.

Woo, K. H. (2015), Representatıve Bureaucracy: The Malaysıan Perspectıve, International Journal of Political Science, Law and International Relations (IJPSLIR) ISSN(P): 2278-8832; ISSN(E): 2278-8840 Vol. 5, Issue 1, Feb 2015, 11-22.

ABD Sivil Haklar $\quad$ Yasası için bkz: https://legcounsel.house.gov/Comps/Civil\%20Rights\%20Act\%20Of\%201964.pdf (19.09.2018) 
Hindistan Anayasası bkz: https://www.india.gov.in/sites/upload_files/npi/files/coi_part_full.pdf (17.09.2018)

Kamu Personel İstatistikleri için bkz: http://www.dpb.gov.tr/tr-tr/istatistikler/kamu-personeli-istatistikleri (17.08.2018)

Kanada Anayasası bkz:http://laws-lois.justice.gc.ca/eng/Const/page-15.html\#h-45 (15.08.2018)

Kanada İnsan Hakları Yasası bkz: http://laws-lois.justice.gc.ca/eng/acts/h-6/page-1.html (15.08.2018)

Kanada İstihdamda Eşitlik Yasası için bkz : http://laws-lois.justice.gc.ca/eng/acts/E-5.401/page2.html\#docCont (13.08.2018)

Kanada Kamu Hizmeti İstihdam Yasası için bkz: http://laws-lois.justice.gc.ca/eng/acts/P-33/page-1.html (13.08.2018)

Kanada Kamu Hizmetinde İstihdam Eşitliği Raporu için bkz:https://www.canada.ca/content/dam/tbssct/documents/reports/eepsfy-emefp/2017/eepsfy-emefp-eng.pdf (13.08.2018)

Kanada Nüfusu bkz: http://countrymeters.info/en/Canada (13.08.2018)

Kanada Kamu İstihdam Sayıs1 için bkz:https://www.canada.ca/en/treasury-boardsecretariat/services/innovation/human-resources- statistics/population-federal-public-service-department.html (13.08.2018)

Kanada'da Engelli Nüfus için bkz: https://easterseals.ca/english/wp.content/uploads/2016/12/Disability-inCanada-Facts-Figures.pdf (13.08.2018)

Kanada'da Aborjin Nüfusu bkz:https://www12.statcan.gc.ca/nhs-enm/2011/as-sa/99-011-x/99-011-x2011001eng.cfm (13.08.2018)

Kanada'da Etnik Çeşitlilik bkz: https://www12.statcan.gc.ca/nhs-enm/2011/as-sa/99-010-x/99-010-x2011001eng.cfm (13.08.2018)

Kanada Kamu Hizmeti Çalışan Anketi bkz:https://www.canada.ca/en/treasury-boardsecretariat/services/innovation/public-service-employee-survey.html (14.08.2018) 